\title{
Molecular characterization of antitumor effects of the rhizome extract from Curcuma zedoaria on human esophageal carcinoma cells
}

\author{
YUNI ELSA HADISAPUTRI ${ }^{1}$, TATSUYA MIYAZAKI ${ }^{1}$, SHIGEMASA SUZUKI $^{1}$, NORIO KUBO ${ }^{1}$, ADE ZUHROTUN $^{3}$, \\ TAKEHIKO YOKOBORI ${ }^{2}$, RIZKY ABDULAH ${ }^{3}$, SHIN YAZAWA ${ }^{1}$ and HIROYUKI KUWANO ${ }^{1}$ \\ Departments of ${ }^{1}$ General Surgical Science and ${ }^{2}$ Molecular and Cellular Pharmacology, Gunma University, \\ Graduate School of Medicine, Maebashi 371-8511, Gunma, Japan; ${ }^{3}$ Department of Pharmacology and Clinical \\ Pharmacy, Faculty of Pharmacy, Universitas Padjadjaran, Jatinangor 45363, Bandung, Indonesia
}

Received August 5, 2015; Accepted September 18, 2015

DOI: $10.3892 /$ ijo.2015.3199

\begin{abstract}
Curcuma zedoaria has been used as a traditional agent against malignant diseases. To elucidate detailed mechanisms producing such an activity, characterization and determination of molecular mechanisms of its antitumor effects was conducted. Inhibiting activities against cell proliferation, invasion and colony formation, and expression levels of corresponding molecules were investigated using human esophageal cancer TE-8 cells treated with the rhizome extract from $C$. zedoaria. Antitumor effect of the extract administered orally was also examined in tumor-bearing mice. The extract possessed strong anti-proliferation and invasion activities against TE-8 cells. Further, upregulated PTEN and downregulated phosphorylated Akt, mTOR and STAT3 expressions in the cells were induced shortly after treatment with the extract, followed by attenuation of FGFR1 and MMP-2, activation of caspase-9, caspase-3 and PARP, and suppression of Bcl-2 expressions, which led the cells to apoptotic cell death. Furthermore, tumor formation in mice was significantly suppressed through the oral administration of the extract. Taken together, these results suggest that the $C$. zedoaria extract could be a promising agent against esophageal cancer.
\end{abstract}

Correspondence to: Dr Yuni Elsa Hadisaputri, Department of General Surgical Science, Gunma University, Graduate School of Medicine, 3-39-22 Showa-machi, Maebashi 371-8511, Gunma, Japan E-mail:m12702030@gunma-u.ac.jp

Abbreviations: CPI, cell proliferation inhibition; PARP, poly(ADPribose) polymerase; PTEN, phosphatase and tensin homolog deleted on chromosome ten; mTOR, mammalian target of rapamycin; STAT3, signal transducer and activator of transcription 3; FGFR1, fibroblast growth factor receptor 1; MMP-2, matrix metalloproteinase-2

Key words: Curcuma zedoaria, esophageal cancer, caspase, Akt/mTOR, apoptosis, angiogenesis, antitumor effects

\section{Introduction}

A series of naturally-occurring substances isolated from the genus Curcuma have been widely used in cooking worldwide, and at the same time, they have been traditionally prescribed against not only general diseases such as wounds, inflammation and fever but also cardiovascular and malignant diseases mostly in Asian countries (1). One of the most common ones is turmeric, which was isolated for the first time in the dried ground rhizome of Curcuma longa (2), and the active constitute identified as the curcumin (3) has been determined to possess a wide variety of effects on inhibitions against proliferation, growth, metastasis, invasion and angiogenesis of tumor cells $(4,5)$. Whereas, the genus Curcuma contains large numbers of species, and various constituents isolated as turmerin, essential oils and curcuminoids including curcumin were reported to produce the same efficacies $(6,7)$. They have been investigated for antioxidant, anti-inflammatory and antitumor activities (8-16), and some were applied in clinical trials $(17,18)$.

Curcuma zedoaria, otherwise known as zedoary or white turmeric, was demonstrated to contain strong cytotoxic activity against tumor cells, and several constituents were identified (14). The extracts from $C$. zedoaria have also been reported to possess anti-mutagenic $(19,20)$, antitumor $(13,21,22)$, antioxidant (23), antimicrobial $(24,25)$, anti-inflammation (26) and antiangiogenesis $(27,28)$ activities. However, detailed mechanisms of their effectiveness still remain to be investigated, and it has been expected that the curcumin possesses various activities to regulate expression of multiple cell signaling proteins (4).

Recently, we synthesized a series of glycans, and demonstrated their potential as antitumor agents against various tumor cells through the induction of apoptosis and autophagy in the cells (29-31). As described previously (29), prognosis of patients suffering from esophageal cancer is still poor irrespective of recently developed treatments with surgery and chemotherapies. Recent studies have also showed that the prevalence of esophageal cancer is expected to increase gradually even though many other types of cancer are expected to decrease in incidence by 2025 (32). 
In this study, the $C$. zedoaria extract prepared from the rhizome with ethanol was investigated both in vitro and in vivo, and its antitumor effects on esophageal cancer cells were elucidated together with determination of molecular mechanisms involved.

\section{Materials and methods}

Materials. The rhizome powder of Curcuma zedoaria (Christm.) Roscoe was obtained from Uchida Wakanyaku Ltd. (Tokyo, Japan). TE-8 cells were purchased from RIKEN BioResource Center (Ibaraki, Japan) and HET-1A cells were from American Type Culture Collection (Manassas, VA, USA). Balb/c nude mice (6-week-old, female) were purchased from Nihon CLEA (Tokyo, Japan). Antibodies against caspase-9, caspase-3, PARP, Bcl-2, PTEN, phospho-Akt, phospho-mTOR, phospho-STAT3, FGFR1 and MMP-2 were obtained from Cell Signaling Technology Inc. (Danvers, MA, USA). Anti- $\beta$-actin and DMSO were purchased from Sigma (St. Louis, MO, USA).

Preparation of C. zedoaria extraction. Eight hundred grams of the rhizome powder from $C$. zedoaria rhizome was extracted three times with $800 \mathrm{ml}$ of ethanol. The combined extracts were then concentrated using a rotary evaporator, and the dried material $(14.02 \mathrm{~g})$ was obtained.

Cell lines. Cell lines used in this study were human esophageal squamous carcinoma (TE-8) (33) and non-cancerous immortalized esophageal cells (HET-1A) (34). The cells were cultured at $37^{\circ} \mathrm{C}$ in RPMI-1640 medium (Sigma) supplemented with $10 \%$ fetal bovine serum and antibiotics $(100 \mathrm{U} / \mathrm{ml}$ penicillin and $100 \mu \mathrm{g} / \mathrm{ml}$ streptomycin).

Cell proliferation assay. Fifty $\mu$ l of a cell suspension $\left(1 \times 10^{4}\right.$ cells $)$ was seeded into each well of a 96-well plate (Falcon, Franklin Lakes, NJ, USA) and incubated at $37^{\circ} \mathrm{C}$ overnight. Fifty $\mu 1$ of medium containing various amounts of the crude extract of C. zedoaria $(7.8-1,000 \mu \mathrm{g} / \mathrm{ml})$, which was dissolved with $10 \%$ DMSO, was added to each well and the plate was incubated at $37^{\circ} \mathrm{C}$ for $24 \mathrm{~h}$. Cell viability was determined with the aid of a cell counting kit (Dojindo, Kumamoto, Japan) according to the manufacturer's instructions. The absorbance at $450 \mathrm{~nm}$ $\left(\mathrm{OD}_{450}\right)$ with the reference wavelength at $620 \mathrm{~nm}$ was read and the results were derived from triplicate experiments. The cell proliferation inhibition (CPI) rate (\%) was calculated by the following formula: $\mathrm{CPI}$ rate $(\%)=\left(1-\mathrm{OD}_{450}\right.$ of the treated cells/ $\mathrm{OD}_{450}$ of the untreated cells) $\mathrm{x} 100$.

Western blot analyses. TE- 8 and HET-1A cells $\left(1 \times 10^{6}\right.$ cell/ $\mathrm{ml})$ were treated with the $C$. zedoaria extract $(100 \mu \mathrm{g} / \mathrm{ml})$ for $24 \mathrm{~h}$. Both cell types incubated for 12 and $24 \mathrm{~h}$ were obtained together with those without treatment as controls. Cells were washed twice in an ice-cold medium and the cell lysate was prepared after solubilizing cells with PRO-PREP Protein Extraction Solution (iNtRON Biotechnology, Gyeonggi-do, Korea). Protein concentrations of the lysate were determined with a Pierce BCA protein assay kit (Thermo Fisher Scientific, Inc., Waltham, MA, USA) using bovine serum albumin as a standard. The extract $(40 \mu \mathrm{g})$ was subjected

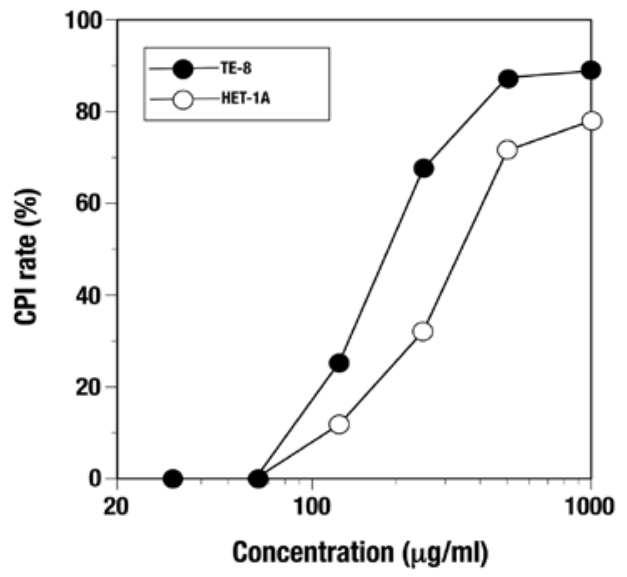

Figure 1. Effect of the $C$. zedoaria extract on the viability of esophageal cells. TE- 8 and HET-1A cells were treated with various concentrations of the $C$. zedoaria extract for $24 \mathrm{~h}$ and the viability was determined using a cell counting kit. CPI, cell proliferation inhibition.

to electrophoresis on a Mini-PROTEAN TGX Precast Gels 4-20\% (Bio-Rad, Tokyo, Japan) and the gel was electrotransferred to a Hybond ECL $(7 \times 8 \mathrm{~cm})$ membrane (GE Life Science Healthcare, Amersham Place, Buckinghamshire, UK). Changes of expression levels of various proteins after treatment with the extract were analyzed using western blotting of each protein. $\beta$-actin was used as a loading control. MagicMark $^{\mathrm{TM}}$ XP Western Protein Standard (Invitrogen Life Science Technology, Waltham, MA, USA), which consists of nine recombinant proteins in the range of $20-220 \mathrm{kDa}$ was used as a loading marker. Bands on the membrane were detected using an Image Quant LAS4000 with the aid of an enhanced chemiluminescence detection system (GE Life Science).

Colony assay. TE- 8 cells were seeded at 250 cells in a $25-\mathrm{cm}^{2}$ cell culture flask (Corning Life Science, Rochester, NY, USA) and incubated for $24 \mathrm{~h}$ and then, after washing with the RPMI medium, the cells were treated with the medium containing the $C$. zedoaria extract with different concentrations for $48 \mathrm{~h}$. Each test was performed in triplicate. After incubation for 10 days with change of medium every 2 days, the number of colonies formed was counted under the microscope (35). The survival rate of colonies (\%) was calculated from the following formula: survival rate $(\%)=$ (numbers of colonies formed after treatment/numbers of colonies formed without treatment) x 100 .

Cell invasion assay. The cell invasion assay was examined in the BD BioCoat ${ }^{\mathrm{TM}}$ Matrigel invasion chamber $(8.0 \mu \mathrm{m}$, BD Bioscience, San Jose, CA, USA) according to the manufacturer's instructions. TE- 8 cells were incubated at $37^{\circ} \mathrm{C}$ for $48 \mathrm{~h}$ with the medium containing the $C$. zedoaria extract with different concentrations. Five hundred $\mu \mathrm{l}$ of treated cells suspension containing $2.5 \times 10^{4}$ cells and $750 \mu \mathrm{l}$ of the medium were added to each invasion chamber. After incubation for $12 \mathrm{~h}$, the cells were stained with a Diff-Quick kit (Sysmex Corp., Kobe, Japan) and observed under the microscope. The five visual fields in every membrane were photographed and all samples were tested in triplicate. 

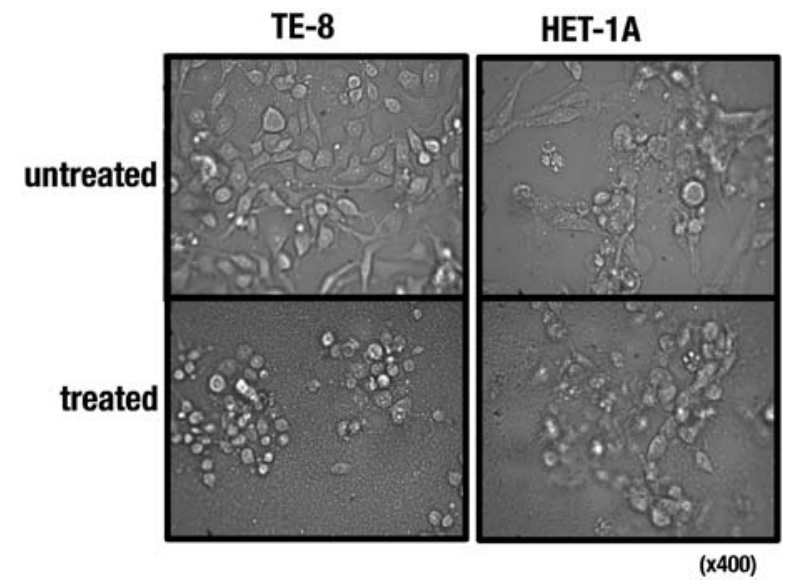

Figure 2. Morphological changes of esophageal cells after treatment with the C. zedoaria extract. Cells were incubated with (treated, $250 \mu \mathrm{g} / \mathrm{ml}$ ) and without (untreated) the extract for $24 \mathrm{~h}$, and photographed using a phasecontrast microscope (x400).

Animal experiments. TE-8 cells were suspended in $100 \mu \mathrm{l}$ of the medium containing $1 \times 10^{6}$ cells and mixed with $100 \mu 1$ of the Matrigel (BD Biosciences). The mixture was then injected subcutaneously into the flank of the Balb/c nude mice (6-week-old, female) according to the method described previously (36). Two hundred $\mu \mathrm{l}$ of $10 \%$ DMSO containing $5 \mathrm{mg}$ of the $C$.zedoaria extract was administered orally everyday with the aid of a disposable feeding needle (Fuchigami Kikai Co., Ltd., Kyoto, Japan). The same treatment with only 10\% DMSO solution was also conducted as controls ( $\mathrm{n}=10$ each). Tumor volume (V) formed was estimated according to the following formula: $\mathrm{V}=1 / 2 \times\left(\mathrm{a}^{2}\right)$, where $\mathrm{V}$, $\mathrm{a}$ and $\mathrm{b}$ indicate the tumor volume in $\mathrm{mm}^{3}$, the smallest and largest tumor size $(\mathrm{mm})$, respectively (37). The mice were sacrificed by euthanasia using Somnopentyl (Kyoritsu Seiyaku Co. Ltd., Tokyo, Japan) on the 29th day after injection of the cells. The experiment was approved by the Animal Care and Experimentation Committee of Gunma University.

Statistical analysis. Statistical analysis was performed using JMP 5.0 software (SAS Institute Inc., NC, USA). The differences were considered statistically significant when the P-value was $<0.05$.

\section{Results}

Effects of the C. zedoaria extract on viability of esophageal cells. Inhibiting activity of the C. zedoaria extract against proliferation was observed at $24 \mathrm{~h}$ in both TE- 8 and HET-1A cells in a dose-dependent manner (Fig. 1). The minimum concentration of the extract giving a $50 \%$ inhibition of cell proliferation inhibition $\left(\mathrm{CPI}_{50}\right)$ in TE-8 cells and HET-1A was 200 and $362.5 \mu \mathrm{g} / \mathrm{ml}$, respectively. Morphological changes of the cells treated with the extract were observed under a microscope (Fig. 2), and cell death seemed to occur faster in TE-8 cells than in HET-1A cells (data not shown).

Western blot analyses of the caspase cascade-related proteins. Since apoptotic cell death seemed to be induced in esophageal cells that had been treated with the $C$. zedoaria extract (Fig. 2), the expression levels of the proteins related to apoptosis were analyzed in both TE-8 and HET-1A cells (Fig. 3). Expression levels of the initiator caspase, caspase- 9 and the effector caspase, caspase- 3 were found to increase in TE-8 cells at $24 \mathrm{~h}$ indicating that active fragments with $37 \mathrm{kDa}$ and $19 \mathrm{kDa}$, increased, respectively by treatment with the extract. Furthermore, the activation of poly(ADP-ribose) polymerase (PARP) seemed to be induced simultaneously since increased levels of the active fragment with $89 \mathrm{kDa}$ were also determined in the same duration. Reversely, the expression levels

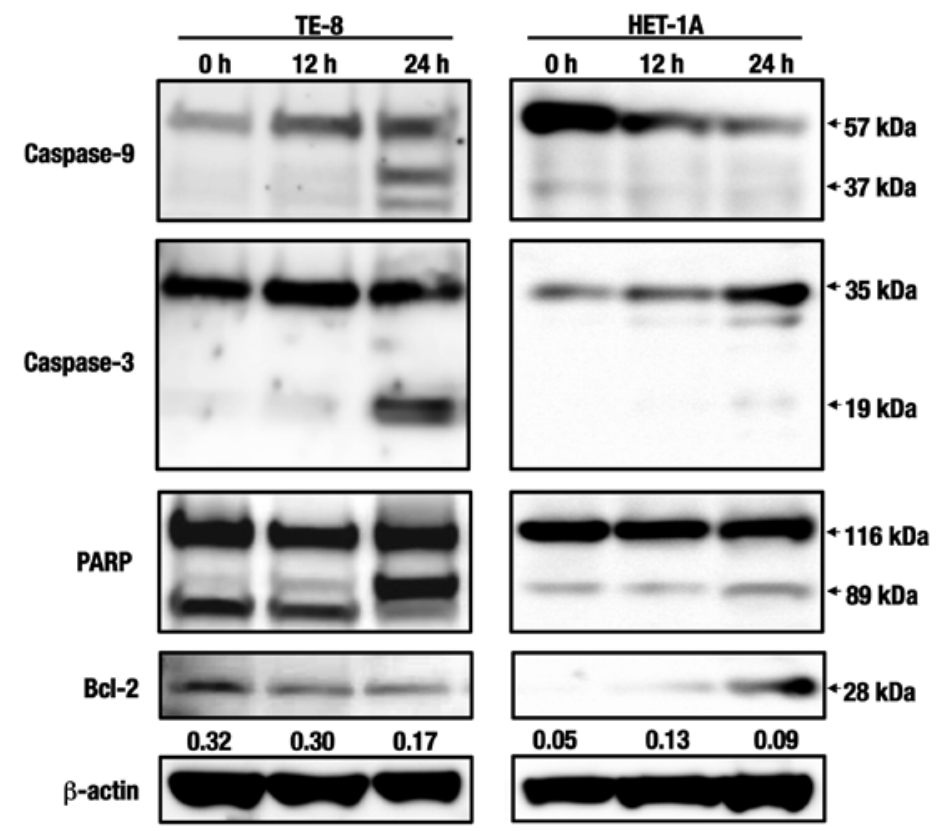

Figure 3. Western blot analysis of the caspase cascade-related proteins in esophageal cells treated with the $C$. zedoaria extract. Changes in the expression level of caspase-9, caspase-3, PARP and Bcl-2 were determined in TE- 8 and HET-1A cells treated with the C. zedoaria extract at 12 and 24 h. The levels given below the Bcl-2 image indicate the calculation of the active form band $(28 \mathrm{kDa})$ of that of $\beta$-actin, shown as a percentage compared with the control. 


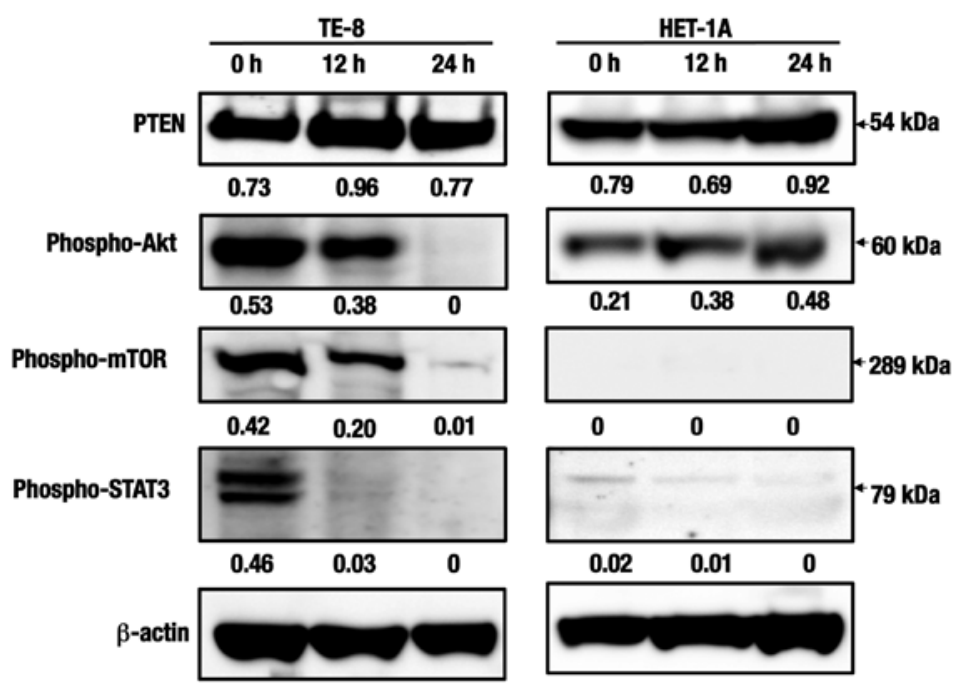

Figure 4. Western blot analysis of the survival-related proteins in esophageal cells treated with the C. zedoaria extract. Changes in the expression level of PTEN, phosphorylated Akt (phospho-Akt), phosphorylated mTOR (phospho-mTOR), phosphorylated STAT3 (phospho-STAT3) were determined in TE-8 and HET-1A cells treated with the C. zedoaria extract at 12 and $24 \mathrm{~h}$. The levels given below each image indicate the calculations as described in Fig. 3 .

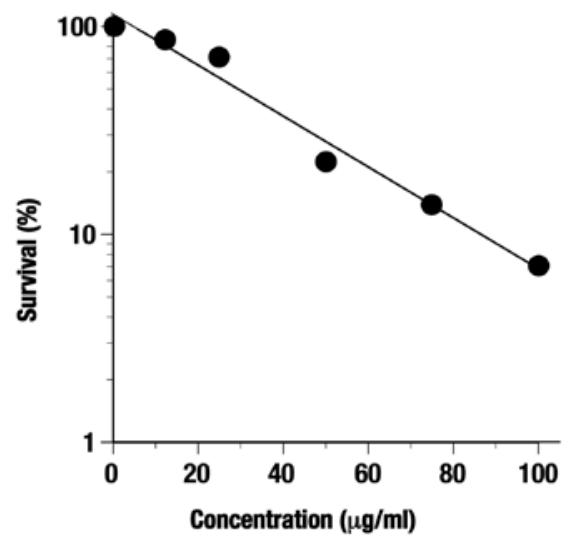

Figure 5. Effect of the C. zedoaria extract on colony formation of TE-8 cells Survival rates of colonies formed by TE-8 cells were determined under the presence of various concentrations of the $C$.zedoaria extract. See the details in Materials and methods.

of one of the anti-apoptotic molecules, Bcl-2, was shown to decrease in the treated TE- 8 cells in a time-dependent manner. No activated fragments were found in caspase-9 or caspase-3 in HET-1A cells treated with the same extract. Expression of PARP and $\mathrm{Bcl}-2$ was slightly detected but no significant change was observed in the cells.

Western blot analyses of the cell survival and proliferationrelated proteins. Expression levels in the phosphatase and tensin homolog deleted on chromosome ten (PTEN) were considerably detected in TE- 8 cells during $24 \mathrm{~h}$ and as maximum at $12 \mathrm{~h}$ after treatment with the $C$. zedoaria extract (Fig. 4). While, expression levels of the activated Akt, as measured by the serine 473 phosphorylation (phospho-Akt), the activated mammalian target of rapamycin (phosphomTOR) were found to be suppressed as early as at $12 \mathrm{~h}$, and no clear expression was detected at $24 \mathrm{~h}$. Further, expression of the phosphorylated signal transducer and activator of transcrip-

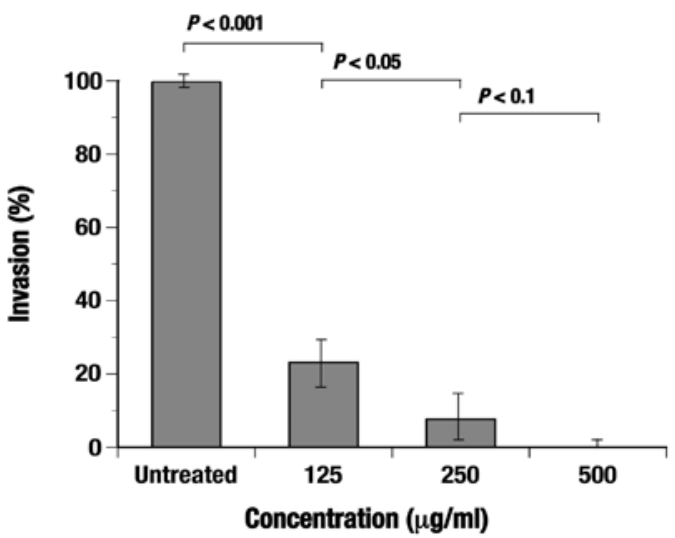

Figure 6. Effect of the $C$. zedoaria extract on invasive activity of TE- 8 cells. TE- 8 cells were incubated for $12 \mathrm{~h}$ under the presence of various concentrations of the $C$. zedoaria extract. Cells that invaded into the matrigel were scored as described in Materials and methods.

tion 3 (phospho-STAT3) seemed to be suppressed early. Even though expression levels of PTEN and phospho-Akt seemed to increase in HET-1A cells at $24 \mathrm{~h}$ with the same treatment, no significant expression of phospho-mTOR or phospho-STAT3 was detected in the same cells.

Effect of the C. zedoaria extract on colony formation of TE- 8 cells. Colony formation of TE- 8 cells determined at 12 days after incubation was shown clearly to be inhibited under the presence of the C. zedoaria extract and survival rates of colonies were found to decrease with the extract added in a dose-dependent manner (Fig. 5).

Effect of the C. zedoaria extract on invasion capacity of TE-8 cells. The cell invasion was significantly $(\mathrm{P}<0.001)$ inhibited under the presence of the extract and the invasion rate was clearly shown to decrease depending on the concentration of the extract added (Fig. 6). 


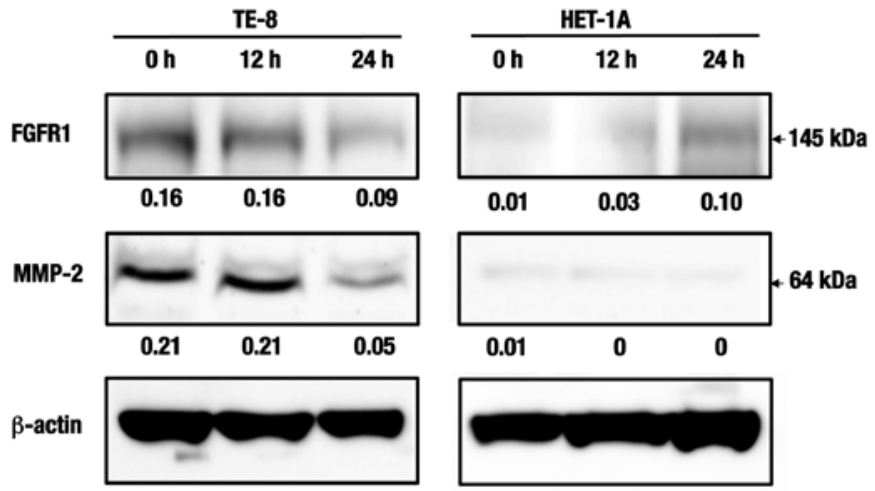

Figure 7. Western blot analysis of the cell invasion and angiogenesis-related proteins in esophageal cells treated with the $C$. zedoaria extract. Changes in the expression level of FGFR1 and MMP-2 were determined in TE-8 and HET-1A cells treated with the C. zedoaria extract at 12 and $24 \mathrm{~h}$. The levels given below each image indicate the calculations as described in Fig. 3.

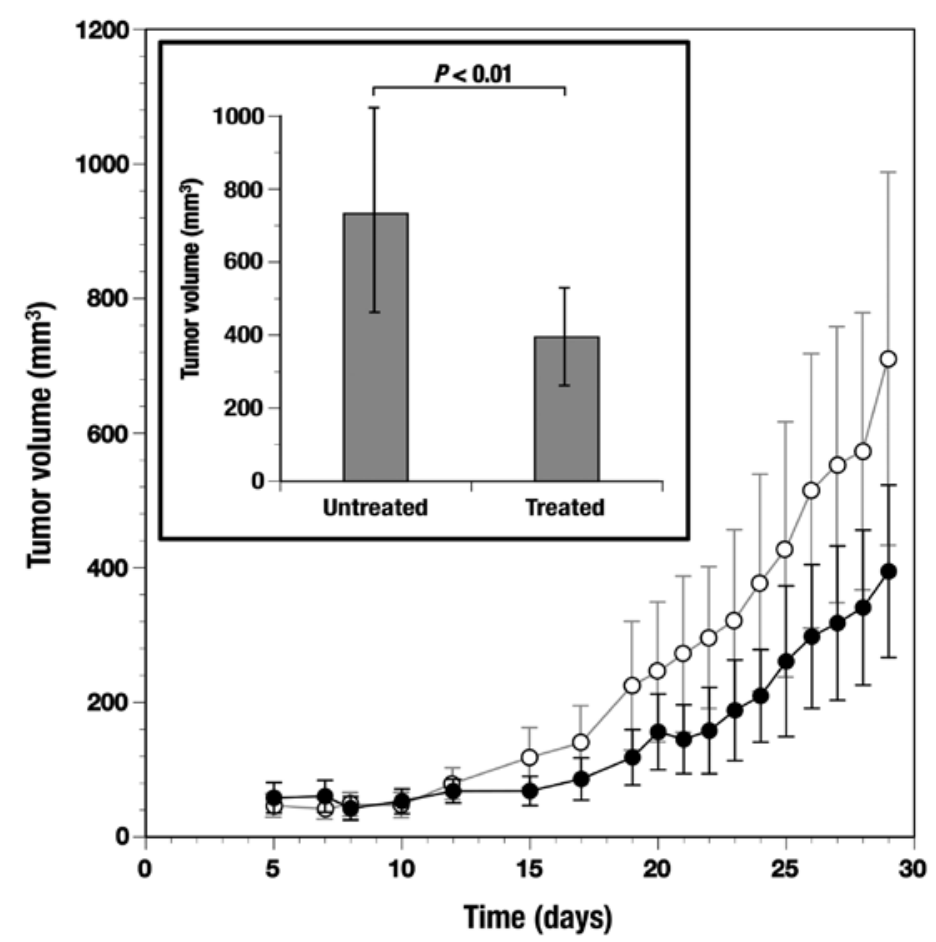

Figure 8. Antitumor effect of the $C$. zedoaria extract on subcutaneously formed tumors with TE- 8 esophageal cancer cells. TE- 8 cells (1x10 ${ }^{6}$ cells) were subcutaneously injected into nude mice ( $\mathrm{n}=10$ each). Injections of the $C$. zedoaria extract $(5 \mathrm{mg})$ were administered orally every day (treated group, black circles). Mice without the extract were also prepared (untreated group, open circles). Tumor formations determined at 29 days in both groups were compared (inset). See the details in Materials and methods.

Western blot analyses of the cell invasion and angiogenesisrelated proteins. Expression levels of the fibroblast growth factor receptor 1 (FGFR1) in TE-8 cells were suppressed at $24 \mathrm{~h}$ after treatment with the C. zedoaria extract. Furthermore, those of the matrix metalloproteinase-2 (MMP-2) were also suppressed at $24 \mathrm{~h}$ in the same cells (Fig. 7). Whereas, no such expression or change was observed in HET-1A cells at the same duration.

Antitumor effect of the C. zedoaria extract in tumor bearing mice. After subcutaneous inoculation with TE- 8 cells, tumors were formed within 8 days in all the mice. Tumor formation in treated and untreated mice was measured periodically up to
29 days (Fig. 8). Tumor formation determined at day 29 was significantly $(\mathrm{P}<0.01)$ suppressed in the mice treated through the oral administration of the C. zedoaria extract when compared to control mice without such an administration (Fig. 8, inset).

\section{Discussion}

The active constituents isolated from the genus Curcumin including $C$. longa and $C$. zedoaria have been demonstrated to possess potent antitumor properties against various human tumor cells. However, clinical applications have been limited because of their poor aqueous solubility and bioavailability even 


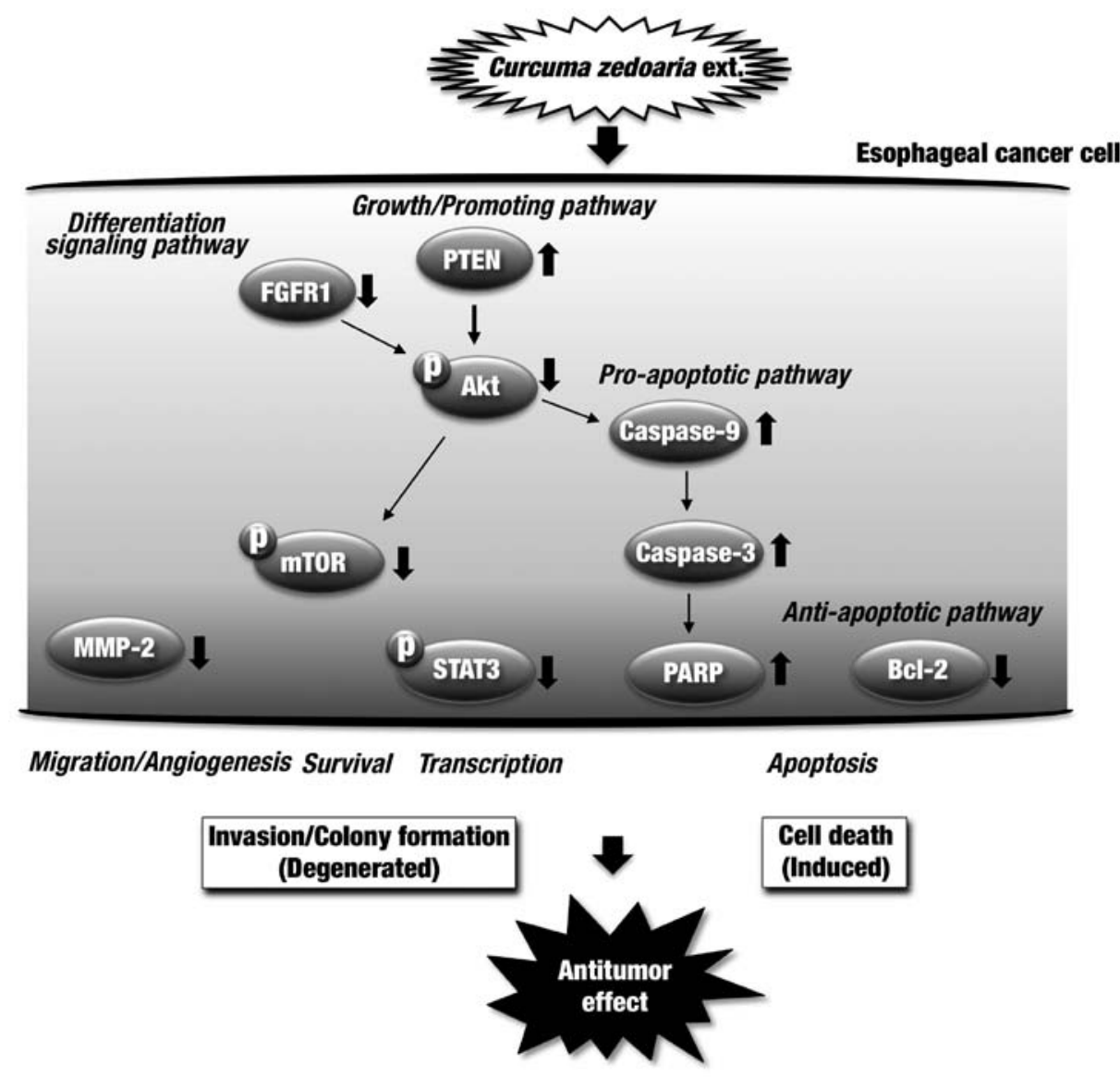

Figure 9. The predicted effects of the C. zedoaria extract on esophageal cancer cells in association with degeneration of invasion and colony formation and induction of cell death. Vertical arrows indicate activation and/or suppression of the expression levels of individual molecules that occurred with treatment of the C. zedoaria extract to the cells.

though a high dose administration and food intake has already been accepted from a standpoint of safety $(7,38)$. Whereas, it has recently been developed for preparing new types of formulations in order to improve their deliveries as anticancer drugs $(38,39)$. The $C$. zedoaria extract has been prepared differently to date, and the methanol or ethanol extract has been characterized to contain numbers of chemical constituents including sesquiterpenes (26), curcuminoids (6) and ethyl $p$-methoxycinnamate (40), which have also been demonstrated to have strong cytotoxic activities against cancer cells $(13,14,41,42)$. While, fractions prepared previously from $C$. zedoaria were reported to possess anti-proliferation activity to varying degree $(16,43)$, which were likely to be caused by the method used in their preparation. The cell proliferation inhibition (CPI) assay against TE-8 and HET-1A cells using various concentrations of the $C$. zedoaria extract indicated strong cytotoxic activities to both esophageal cell types in a dose-dependent manner (Fig. 1). However, when minimum concentrations of the extract at $\mathrm{CPI}_{50}$ were compared, the level in TE- 8 cells were 1.8 -fold lower than the HET-1A cells suggesting that cancer cells seemed to be more susceptible to the extract resulting in induction of apoptosis in TE-8 cells within a short period after treatment with the $C$. zedoaria extract. In fact, morphological changes of TE-8 cells (Fig. 2) were observed within $5 \mathrm{~h}$ after treatment with the extract (data not shown).

Western blot analyses in this study clearly suggested that the induction of apoptosis in TE- 8 cells treated with the $C$. zedoaria extract occurred through the caspase cascade-dependent pathways, which involved activation of caspase-9, caspase-3 and PARP along with suppression of Bcl-2 during $24 \mathrm{~h}$, and resulted in the induction of cell death (Fig. 3). Involvement of caspase-3 activation in the induction of apoptotic cell death has also been demonstrated recently in different cancer cells treated with $C$. zedoaria (43). Interestingly, such an induction of the caspase cascade causing apoptotic cell death seemed to scarcely occur in noncancerous HET-1A cells. Delayed and poorly increased levels of caspase cascade pathways causing apoptotic cell death were also found to occur in non-cancerous esophageal (CHEK-1) cells when compared to esophageal cancer (TE-2 and TE-13) cells treated with chemically synthesized compounds in our previous study (29).

Mechanism of cell death has been accepted to be governed not only by upregulation of the proapoptotic pathway or downregulation of the anti-apoptotic pathway but also by modulation of the survival signaling pathways (44). In the cell survival signaling pathways, PTEN is one of the most common tumor suppressors and negative regulators of downstream effectors $(45,46)$. Expression levels of PTEN were demonstrated to be elevated as early as $12 \mathrm{~h}$ after treatment with $C$. zedoaria extract in TE-8 cells and suppression of Akt activation, which determined by expression levels of phosphorylated Akt (phospho-Akt) on Ser473, occurred at the same duration (Fig. 4). Accordingly, treatment of TE-8 cells with the 
C. zedoaria extract induced PTEN activation accompanying by Akt suppression within a short duration $(<12 \mathrm{~h})$.

As demonstrated previously, elevated levels of phosphorylation occurred in Akt, mTOR, and their downstream molecules to change p-mTOR and corresponding P-molecules were detected in malignant tumor cells (47). The Akt/mTOR signaling pathway comprising mTOR and the downstream Akt must play a crucial role in the survival of their cells. It was clearly determined that expression of p-mTOR was also suppressed within $12 \mathrm{~h}$ after treatment with the $C$. zedoaria extract. Previously, it was shown that the anti-proliferation effect of curcumin was mediated by induction of suppressed levels of phosphorylation of mTOR but at the same time suppression of expression levels of phosphorylation of Akt on its Ser473 at a longer duration of the treatment (72 h) (47). Further, overexpression of PTEN has been demonstrated to induce apoptosis through Akt-dependent and -independent pathways in breast cancer cells (48). It still need confirmation, but the presence of multiple feedback loops has been described previously in the regulation of Akt/mTOR signaling pathway involved in the phosphatase-dependent effects of curcumin against prostate cancer cells (49). It must therefore be plausible that the $C$. zedoaria extract mediated upregulation of anti-proliferation signaling in TE-8 cells first accompanied by apoptotic cell death via upregulation of caspase cascade signaling. While in HET-1A cells, expressions of PTEN and p-Akt were observed with a slight increase, but no significant expression was found in p-mTOR or p-STAT3 during $24 \mathrm{~h}$. It must indicate that no clear change of the phosphatase- and caspase cascade-dependent signaling pathways assumed in TE-8 cells occurred in HET-1A cells after treatment with $C$. zedoaria extract.

Cleavage of PTEN through phosphorylation was found to occur by caspase-3 indicating that PTEN was also targeted by caspase- 3 due to a potential regulatory mechanism under some physiological conditions (50). Since caspase-9 is a one of downstream substrates of Akt and phosphorylated Akt targets a number of downstream substrates including caspases, suppressed expressions of p-Akt may induce the inhibition of phosphorylation of caspase(s) resulting in apoptotic cell death.

Effects of curcumin were investigated previously on inhibition of STAT3 phosphorylation in human multiple myeloma cells and it was demonstrated that inhibition of STAT3 phosphorylation induced by curcumin was reversible and occurred rapidly (51). In this study, downregulation of STAT3 occurred as early as $12 \mathrm{~h}$ after treatment with the extract in TE-8 cells (Fig. 4). Further investigation to determine the precise mechanisms and other signaling pathways involved in the cell death is required to be conducted; this should comprise a series of complex signaling pathways, some of which should cross-talk each other in cancer cells possessing large numbers of dysregulated proteins.

In receptor tyrosine kinases, the fibroblast growth factor receptor (FGFR) consists of four highly conserved receptor tyrosine kinases (52). It was suggested previously that FGFR could also be a target for anticancer agent development, and that FGFR inhibitors have potential for therapeutic application as anticancer agents $(53,54)$. In TE- 8 cells, it was found that expression of FGFR1 reduced at $24 \mathrm{~h}$ after treatment with the $C$. zedoaria extract (Fig. 7), but the predicted effects of inhibition effects on the downstream signaling pathways such as the Akt signaling pathway occurred as early as $12 \mathrm{~h}$.

Angiogenesis has been demonstrated to be essential for solid tumor growth because tumor progression and metastasis depend on the existence of a functional blood supply system as reported previously (55). The MMP-2, one of the matrix metalloproteinases, involved in an extracellular matrix degrader has an important role in the endothelial cell migration, organization and angiogenesis (56). The active form of MMP-2 (62 kDa) might facilitate penetration of cancer cells through the blood vessel walls allowing them to metastasize to other tissues or organs (57). Since extremely reduced expression of MMP-2 preferentially occurred in TE- 8 cells treated with the $C$. zedoaria extract at $24 \mathrm{~h}$, it was suggested that the extract has potentially diverse effects on anti-proliferation, survival, angiogenesis, migration and organization. In fact, some of these activities in the extract were also shown clearly through the colony assay (Fig. 5) and the cell invasion assay (Fig. 6) indicating that the extract possessed significant inhibiting activity against colony formation and cell migration of TE- 8 cells. Finally, tumor formation with esophageal TE-8 cancer cells was significantly suppressed in the mice orally administered with the $C$. zedoaria extract (Fig. 8). Taken together, therefore, the $C$. zedoaria extract could be promising as an antitumor agent against esophageal cancer.

Presence of constituents involving antitumor activities has been reported in the same ethanol extract from $C$. zedoaria as described above. Identification of the active constituents in the $C$. zedoaria extract is now in progress along with determination of the best route for administration of the extract with appropriate dose and duration in order to apply this natural product into a novel therapy against esophageal cancer.

In conclusion, treatment of esophageal cancer cells with the $C$.zedoaria extract was shown to have antitumor action in in vitro and in vivo experiments. In addition, tumor formation was significantly suppressed in the xenograft mouse model of human esophageal cancer through the oral administration of the extract. Overall results from the effects of the $C$. zedoaria extract are summarized in Fig. 9. The $C$. zedoaria extract possesses useful constituents to modulate multi-targets against dysregulated proteins in esophageal tumor cells, and shows promise as an agent against esophageal cancer.

\section{Acknowledgements}

This study was supported in part by the following grants: Grants-in-Aid for Scientific Research from the Japan Society for the Promotion of Science (JSPS nos. 22591450 and 23591857).

\section{References}

1. Mishra BB and Tiwari VK: Natural products: An evolving role in future drug discovery. Eur J Med Chem 46: 4769-4807, 2011.

2. Kuttan R, Bhanumathy P, Nirmala K and George MC: Potential anticancer activity of turmeric (Curcuma longa). Cancer Lett 29: 197-202, 1985.

3. Negi PS, Jayaprakasha GK, Jagan Mohan Rao L and Sakariah KK: Antibacterial activity of turmeric oil: A byproduct from curcumin manufacture. J Agric Food Chem 47: 4297-4300, 1999.

4. Kunnumakkara AB, Anand P and Aggarwal BB: Curcumin inhibits proliferation, invasion, angiogenesis and metastasis of different cancers through interaction with multiple cell signaling proteins. Cancer Lett 269: 199-225, 2008. 
5. Hasima N and Aggarwal BB: Cancer-linked targets modulated by curcumin. Int J Biochem Mol Biol 3: 328-351, 2012.

6. Kuroyanagi $\mathrm{M}$ and Natori S: Some observation on curcuminoids from Zingiberaceae plants. Yakugaku Zasshi 90: 1467-1470, 1970 (In Japanese).

7. Sharma RA, Gescher AJ and Steward WP: Curcumin: The story so far. Eur J Cancer 41: 1955-1968, 2005.

8. Kuo ML, Huang TS and Lin JK: Curcumin, an antioxidant and anti-tumor promoter, induces apoptosis in human leukemia cells. Biochim Biophys Acta 1317: 95-100, 1996.

9. Mehta K, Pantazis P, McQueen T and Aggarwal BB: Antiproliferative effect of curcumin (diferuloylmethane) against human breast tumor cell lines. Anticancer Drugs 8: 470-481, 1997.

10. Chen H, Zhang ZS, Zhang YL and Zhou DY: Curcumin inhibits cell proliferation by interfering with the cell cycle and inducing apoptosis in colon carcinoma cells. Anticancer Res 19: 3675-3680, 1999.

11. Motterlini R, Foresti R, Bassi R and Green CJ: Curcumin, an antioxidant and anti-inflammatory agent, induces heme oxygenase-1 and protects endothelial cells against oxidative stress. Free Radic Biol Med 28: 1303-1312, 2000.

12. Kunnumakkara AB, Guha S, Krishnan S, Diagaradjane $\mathrm{P}$, Gelovani J and Aggarwal BB: Curcumin potentiates antitumor activity of gemcitabine in an orthotopic model of pancreatic cancer through suppression of proliferation, angiogenesis, and inhibition of nuclear factor-kappaB-regulated gene products. Cancer Res 67: 3853-3861, 2007.

13. Chen CC, Chen Y, Hsi YT, Chang CS, Huang LF, Ho CT, Way TD and Kao JY: Chemical constituents and anticancer activity of Curcuma zedoaria roscoe essential oil against non-small cell lung carcinoma cells in vitro and in vivo. J Agric Food Chem 61: 11418-11427, 2013.

14. Syu WJ, Shen CC, Don MJ, Ou JC, Lee GH and Sun CM: Cytotoxicity of curcuminoids and some novel compounds from Curcuma zedoaria. J Nat Prod 61: 1531-1534, 1998.

15. Chen X, Pei L, Zhong Z, Guo J, Zhang Q and Wang Y: Anti-tumor potential of ethanol extract of Curcuma phaeocaulis Valeton against breast cancer cells. Phytomedicine 18: 1238-1243, 2011.

16. Liu Y, Roy SS, Nebie RHC, Zhang Y and Nair MG: Functional food quality of Curcuma caesia, Curcuma zedoaria and Curcuma aeruginosa endemic to Northeastern India. Plant Foods Hum Nutr 68: 72-77, 2013.

17. Kanai M, Otsuka Y, Otsuka K, Sato M, Nishimura T, Mori Y, Kawaguchi M, Hatano E, Kodama Y, Matsumoto S, et al: A phase I study investigating the safety and pharmacokinetics of highly bioavailable curcumin $\left(\right.$ Theracurmin $\left.^{\circledR}\right)$ in cancer patients. Cancer Chemother Pharmacol 71: 1521-1530, 2013.

18. Belcaro G, Hosoi M, Pellegrini L, Appendino G, Ippolito E, Ricci A, Ledda A, Dugall M, Cesarone MR, Maione C, et al: A controlled study of a lecithinized delivery system of curcumin $\left(\right.$ Meriva $\left.^{\circledR}\right)$ to alleviate the adverse effects of cancer treatment. Phytother Res 28: 444-450, 2014.

19. Lee $\mathrm{H}$ and Lin JY: Antimutagenic activity of extracts from anticancer drugs in Chinese medicine. Mutat Res 204: 229-234, 1988

20. Peng CH, Chiu WT, Juan CW, Mau JL, Chen CC, Peng CC, Lai EY and Chyau CC: Pivotal role of curcuminoids on the antimutagenic activity of Curcuma zedoaria extracts. Drug Chem Toxicol 33: 64-76, 2010.

21. Kim KI, Kim JW, Hong BS, Shin DH, Cho HY, Kim HK and Yang HC: Antitumor, genotoxicity and anticlastogenic activities of polysaccharide from Curcuma zedoaria. Mol Cells 10: 392-398, 2000

22. Seo WG, Hwang JC, Kang SK, Jin UH, Suh SJ, Moon SK and Kim CH: Suppressive effect of Zedoariae rhizoma on pulmonary metastasis of B16 melanoma cells. J Ethnopharmacol 101: 249-257, 2005

23. Mau J, Lai EYC, Wang N, Chen C, Chang C and Chyau C: Composition and antioxidant activity of the essential oil from Curcuma zedoaria. Food Chem 82: 583-591, 2003.

24. Lai EY, Chyau CC, Mau JL, Chen CC, Lai YJ, Shih CF and Lin LL: Antimicrobial activity and cytotoxicity of the essential oil of Curcuma zedoaria. Am J Chin Med 32: 281-290, 2004

25. Wilson B, Abraham G, Manju VS, Mathew M, Vimala B, Sundaresan S and Nambisan B: Antimicrobial activity of Curcuma zedoaria and Curcuma malabarica tubers. J Ethnopharmacol 99: 147-151, 2005.

26. Makabe H, Maru N, Kuwabara A, Kamo T and Hirota M: Antiinflammatory sesquiterpenes from Curcuma zedoaria. Nat Prod Res 20: 680-685, 2006.
27. Chen W, Lu Y, Gao M, Wu J, Wang A and Shi R: Antiangiogenesis effect of essential oil from Curcuma zedoaria in vitro and in vivo. J Ethnopharmacol 133: 220-226, 2011.

28. Zhou L, Zhang K, Li J, Cui X, Wang A, Huang S, Zheng S, Lu Y and Chen W: Inhibition of vascular endothelial growth factormediated angiogenesis involved in reproductive toxicity induced by sesquiterpenoids of Curcuma zedoaria in rats. Reprod Toxicol 37: 62-69, 2013.

29. Faried A, Faried LS, Nakagawa T, Yamauchi T, Kitani M, Sasabe H, Nishimura T, Usman N, Kato H, Asao T, et al: Chemically synthesized sugar-cholestanols possess a preferential anticancer activity involving promising therapeutic potential against human esophageal cancer. Cancer Sci 98: 1358-1367, 2007.

30. Hashimoto S, Yazawa S, Asao T, Faried A, Nishimura T, Tsuboi K, Nakagawa T, Yamauchi T, Koyama N, Umehara K, et al: Novel sugar-cholestanols as anticancer agents against peritoneal dissemination of tumor cells. Glycoconj J 25: 531-544, 2008.

31. Faried A, Arifin MZ, Ishiuchi S, Kuwano H and Yazawa S: Enhanced expression of proapoptotic and autophagic proteins involved in the cell death of glioblastoma induced by synthetic glycans. J Neurosurg 120: 1298-1308, 2014.

32. Napier KJ, Scheerer M and Misra S: Esophageal cancer: A Review of epidemiology, pathogenesis, staging workup and treatment modalities. World J Gastrointest Oncol 6: 112-120, 2014.

33. Nishihira T, Hashimoto Y, Katayama M, Mori S and Kuroki T: Molecular and cellular features of esophageal cancer cells. J Cancer Res Clin Oncol 119: 441-449, 1993.

34. Stoner GD, Kaighn ME, Reddel RR, Resau JH, Bowman D, Naito Z, Matsukura N, You M, Galati AJ and Harris CC: Establishment and characterization of SV40 T-antigen immortalized human esophageal epithelial cells. Cancer Res 51: 365-371, 1991.

35. Franken NAP, Rodermond HM, Stap J, Haveman J and van Bree C: Clonogenic assay of cells in vitro. Nat Protoc 1: 2315-2319, 2006.

36. Pretlow TG, Delmoro CM, Dilley GG, Spadafora CG and Pretlow TP: Transplantation of human prostatic carcinoma into nude mice in Matrigel. Cancer Res 51: 3814-3817, 1991.

37. Gorelik B, Ziv I, Shohat R, Wick M, Hankins WD, Sidransky D and Agur Z: Efficacy of weekly docetaxel and bevacizumab in mesenchymal chondrosarcoma: A new theranostic method combining xenografted biopsies with a mathematical model. Cancer Res 68: 9033-9040, 2008.

38. Mach CM, Mathew L, Mosley SA, Kurzrock R and Smith JA: Determination of minimum effective dose and optimal dosing schedule for liposomal curcumin in a xenograft human pancreatic cancer model. Anticancer Res 29: 1895-1899, 2009.

39. Kim TH, Jiang HH, Youn YS, Park CW, Tak KK, Lee S, Kim H, Jon S, Chen X and Lee KC: Preparation and characterization of water-soluble albumin-bound curcumin nanoparticles with improved antitumor activity. Int J Pharm 403: 285-291, 2011.

40. Gupta SK, Banerjee AB and Achari B: Isolation of Ethyl p-methoxycinnamate, the major antifungal principle of Curcuma zedoaria. Lloydia 39: 218-222, 1976.

41. Carvalho FR, Vassao RC, Nicoletti MA and Maria DA: Effect of Curcuma zedoaria crude extract against tumor progression and immunomodulation. J Venom Anim Toxins Incl Trop Dis 16: 324-341, 2010.

42. Shin Y and Lee Y: Cytotoxic activity from Curcuma zedoaria through mitochondrial activation on ovarian cancer cells. Toxicol Res 29: 257-261, 2013.

43. Syed Abdul Rahman SN, Abdul Wahab N and Abd Malek SN In vitro morphological assessment of apoptosis induced by antiproliferative constituents from the rhizomes of Curcuma zedoaria. Evid Based Complement Alternat Med 2013: 257108, 2013.

44. Fraser M, Leung B, Jahani-Asl A, Yan X, Thompson WE and Tsang BK: Chemoresistance in human ovarian cancer: The role of apoptotic regulators. Reprod Biol Endocrinol 1: 66, 2003.

45. Blanco-Aparicio C, Renner O, Leal JF and Carnero A: PTEN, more than the AKT pathway. Carcinogenesis 28: 1379-1386, 2007.

46. Georgescu MM: PTEN tumor suppressor network in PI3K-Akt pathway control. Genes Cancer 1: 1170-1177, 2010.

47. Johnson SM, Gulhati P, Arrieta I, Wang X, Uchida T, Gao T and Evers BM: Curcumin inhibits proliferation of colorectal carcinoma by modulating Akt/mTOR signaling. Anticancer Res 29: 3185-3190, 2009.

48. Weng L, Brown J and Eng C: PTEN induces apoptosis and cell cycle arrest through phosphoinositol-3-kinase/Akt-dependent and -independent pathways. Hum Mol Genet 10: 237-242, 2001. 
49. Yu S, Shen G, Khor TO, Kim JH and Kong AN: Curcumin inhibits Akt/mammalian target of rapamycin signaling through protein phosphatase-dependent mechanism. Mol Cancer Ther 7: 2609-2620, 2008.

50. Torres J, Rodriguez J, Myers MP, Valiente M, Graves JD, Tonks NK and Pulido R: Phosphorylation-regulated cleavage of the tumor suppressor PTEN by caspase-3: Implications for the control of protein stability and PTEN-protein interactions. J Biol Chem 278: 30652-30660, 2003.

51. Bharti AC, Donato N and Aggarwal BB: Curcumin (diferuloylmethane) inhibits constitutive and IL-6-inducible STAT3 phosphorylation in human multiple myeloma cells. J Immunol 171: 3863-3871, 2003

52. Liang G, Liu Z, Wu J, Cai Y and Li X: Anticancer molecules targeting fibroblast growth factor receptors. Trends Pharmacol Sci 33: 531-541, 2012.

53. Katoh M and Nakagama H: FGF receptors: Cancer biology and therapeutics. Med Res Rev 34: 280-300, 2014.
54. Hu Y, Lu H, Zhang J, Chen J, Chai Z and Zhang J: Essential role of AKT in tumor cells addicted to FGFR. Anticancer Drugs 25: 183-188, 2014.

55. Jubb AM, Oates AJ, Holden S and Koeppen H: Predicting benefit from anti-angiogenic agents in malignancy. Nat Rev Cancer 6: 626-635, 2006

56. Li A, Varney ML, Valasek J, Godfrey M, Dave BJ and Singh RK: Autocrine role of interleukin-8 in induction of endothelial cell proliferation, survival, migration and MMP-2 production and angiogenesis. Angiogenesis 8: 63-71, 2005.

57. Peng JM, Chen YH, Hung SW, Chiu CF, Ho MY, Lee YJ, Lai TC, Hsiao M, Liang CM and Liang SM: Recombinant viral protein promotes apoptosis and suppresses invasion of ovarian adenocarcinoma cells by targeting $\alpha 5 \beta 1$ integrin to down-regulate Akt and MMP-2. Br J Pharmacol 165: 479-493, 2012. 